\title{
Pengembangan Hypothetical Learning Trajectory Topik Pola Bilangan Berbasis Realistic Mathematic Education
}

\author{
Eka Pasca Suryabayu ${ }^{*}$, Ahmad Fauzan ${ }^{2}$, Armiati $^{3}$ \\ ${ }^{1}$ Universitas Muhammadiyah Sumatera Barat (UMSB), Padang, Indonesia \\ ${ }^{2,3}$ Universitas Negeri Padang (UNP), Padang, Indonesia \\ *Corresponding Author
}

Informasi Artikel

Diterima Redaksi: 4 Februari 2021

Revisi Akhir: 22 Maret 2021

Diterbitkan Online: 30 Juni 2021

\begin{tabular}{l} 
Kata Kunci \\
\hline Hypothetical Learning Trajectory, RME \\
Korespondensi \\
\hline E-mail: ekapascha.suryabayu@gmail.com
\end{tabular}

\author{
A B S T R A C T
}

This study aims to produce a Hypothetical Learning Trajectory (HLT) in helping students understand the concept of number patterns. The research method used is design research. The research is focused on designing HLT which is validated, revised and tested one-to-one for students. Research data were collected through observation, interviews, and analysis of student answers. The instruments used are HLT and student worksheets using the Realistic Mathematics Education (RME) approach through literature study. The collected data were collected and analyzed qualitatively. This research was conducted at the Non-Formal Education Program Package A level 2, involving 3 students with high, medi um and low ability levels. The results of the analysis show that students with medium and high abilities can understand the material quite well, while students with low abilities have difficulty understanding the problems given.

Penelitian ini bertujuan untuk menghasilkan Hypothetical Learning Trajectory (HLT) dalam membantu peserta didik dalam memahami konsep pola bilangan. Metode penelitian yang digunakan adalah penelitian desain. Penelitian difokuskan untuk merancang HLT yang divalidasi, direvisi dan diujicobakan secara one-to-one kepada peserta didik. Data penelitian dikumpulkan melalui observasi, wawancara, dan analisis jawaban peserta didik. Instrument yang digunakan berupa HLT dan lembar kerja peserta didik dengan menggunakan pendekatan Realistic Mathematics Education (RME) melalui studi literature. Data yang dikumpulkan dikumpulkan dianalisis secara kualitatif. Penelitian ini dilakukan pada Pendidikan Non Formal Program Paket A tingkat 2, dengan melibatkan 3 orang peserta didik dengan tingkat kemampuan tinggi, sedang dan rendah. Hasil analisis menunjukkan bahwa peserta didik dengan kemampuan sedang dan tinggi dapat memahami materi cukup baik, sedangkan peserta didik kemampuan rendah mengalami kesulitan dalam memahami masalah yang diberikan. (https://creativecommons.org/licenses/by-sa/4.0/)

\section{Pendahuluan}

Matematika memiliki banyak manfaat dalam aktivitas kehidupan sehari-hari manusia. Kebutuhan terhadap matematika menuntut semua pihak untuk dapat bekerja sama memperbaiki kualitas pembelajaran, mulai dari kualitas guru, memperbaharui kurikulum, mengembangkan model atau metode pembelajaran, serta melakukan penelitian untuk memperbaiki kekeliruan yang dimiliki peserta didik [8]. Guru sebagai perencana yang mengantarkan peserta didik untuk mencapai tujuan pembelajaran bertanggungjawab dalam menjamin kualitas pembelajaran yang baik. [5] menyatakan bahwa, secara umum ketidakefektifan dan rendahnya nilai peserta didik disebabkan oleh minimnya penguasaan matematika dasar mereka. Hal tersebut juga diperkuat dengan prestasi Indonesia dalam bidang matematika dari tingkat sekolah dasar hingga tingkat universitas yang masih belum memuaskan. PISA menguji kompetensi dasar yang meliputi bilangan, aljabar, geometri, dan pengukuran. Hasil PISA 2018 dengan indikator dan metode yang digunakan untuk survei PISA 2015 dan 2018 sama. Hal yang membedakan, jika tahun 2015 ada 70 negara yang disurvei, maka tahun 2018 bertambah menjadi 79 negara. Untuk kategori matematika, Indonesia berada di peringkat 73 dengan skor rata-rata 379 . 
Fenomena yang terjadi membutuhkan solusi guna perbaikan pembelajaran. Salah satu solusi yang ditawarkan adalah pendekatan Realistic Mathematics Education (RME), pendekatan ini dapat merangsang peserta didik untuk menggunakan pengetahuan informal dan strategi untuk memecahkan masalah [7]. Realistic Mathematics Education (RME) merupakan sebuah pendekatan pembelajaran yang dikembangkan berdasarkan pemikiran. Hans Freudenthal Freudenthal menyatakan bahwa "Mathematics is human activity". Ini artinya bahwa pembelajaran matematika disarankan berangkat dari aktivitas manusia. [2] menjelaskan maksud dari matematika sebagai aktivitas manusia adalah bahwa manusia perlu diberi kesempatan untuk menemukan kembali ide dan konsep matematika dengan bimbingan orang dewasa. Menurut [2], ada tiga prinsip utama RME yang perlu diperhatikan dalam merancang pembelajaran. Tiga prinsip RME yaitu (1) penemuan terbimbing melalui proses matematisasi progresif, (2) fenomena didaktik, dan (3) pembentukan model oleh siswa sendiri.

Treffers [9] merumuskan lima karakteristik RME yaitu sebagai berikut. (a) Menggunakan masalah kontekstual. Penggunaan konteks nyata (real konteks) sebagai starting point dalam pembelajaran untuk dieksplorasi. (b) Menggunakan model atau jembatan sebagai instrumen vertikal. penggunaan model-model, istilah model berkaitan dengan model situasi dan model matematik yang dikembangkan oleh peserta didik sendiri (self developed models). Peran self developed models merupakan jembatan bagi peserta didik dari situasi real ke situasi abstrak atau dari matematika informal ke matematika formal. Artinya peserta didik membuat model sendiri dalam menyelesaikan masalah, model situasi yang dekat dengan dunia nyata peserta didik. (c) Menggunakan kontribusi siswa. dengan pembuatan "Produksi bebas". Peserta didik terdorong untuk melakukan refleksi pada bagian yang mereka anggap penting dalam proses belajar. Strategi-strategi informal peserta didik yang berupa prosedur pemecahan masalah kontekstual merupakan sumber inspirasi dalam pengembangan pembelajaran lebih lanjut yaitu untuk mengkonstruksi pengetahuan matematika formal. Guru hanya bertindak sebagai fasilitator, moderator, dan evaluator. (d) Interaktifitas. Secara eksplisit, bentuk-bentuk interaksi yang berupa negosiasi, penjelasan, pembenaran, setuju, tidak setuju, pertanyaan atau refleksi digunakan untuk mencapai bentuk formal dari bentuk-bentuk informal peserta didik. (e) Keterkaitan yaitu terintegrasi dengan topik pembelajaran lainnya. Pendekatan holistik, guna pencapaian unit-unit belajar tidak dapat terpisah namun terkait secara integrasi yang harus dieksploitasi dalam pemecahan masalah.

RME membutuhkan sebuah desain alur belajar untuk implementasi dalam proses pembelajaran. Desain alur belajar tersebut mencakup Hypothetical Learning Trajectory (HLT) dengan menggunakan penelitian desain dari Gravemeijer dan Cobb. HLT merupakan prediksi atas proses alur pembelajaran yang mengacu pada rencana pembelajaran berdasarkan pada antisipasi belajar peserta didik. Ada tiga komponen utama dari learning trajectory, yaitu: tujuan pembelajaran (learning goals), kegiatan pembelajaran (learning activities) dan hipotesis proses belajar siswa (hypothetical learning process) yang mengantisipasi bagaimana mengembangkan proses berpikir matematis siswa.

Berdasarkan deskripsi di atas, penelitian ini bertujuan mengembangkan alur belajar (learning trajectory) untuk materi pola bilangan. Alur belajar ini didesain sedemikian rupa sehingga membantu peserta didik menemukan konsep formal melalui masalah kontekstual serta proses matematisasi baik horizontal maupun vertikal. Rumusan masalah pada penelitian ini adalah: Bagaimanakah penerapan hypothetical learning trajectory pada topik pola bilangan di Paket A tingkat 2?

Produk yang dihasilkan adalah alur belajar berbasis RME dengan produk awal berupa HLT. HLT ini diimplementasikan pada peserta didik Paket A tingkat 2. Materi pola bilangan yang dikembangkan terdiri atas 1) menentukan pola bilangan, 2) memprediksi pola bilangan 
yang berkaitan dengan kumpulan benda/gambar/ gerakan, dan 3) menyelesaikan masalah yang berkaitan dengan pola bilangan.

\section{Metode Penelitian}

Metode yang digunakan dalam penelitian ini adalah penelitian desain oleh [2]. Penelitian desain dilakukan dengan merancang pembelajaran mengenai pola bilangan menggunakan pendekatan RME. Implementasi penelitian ini dibantu menggunakan instrumen berupa Hypothetical Learning Trajectory (HLT) dan lembar kerja peserta didik. Penelitian desain yang dikemukakan oleh Gravemeijer and Cobb difokuskan untuk mengembangkan urutan penyajian materi dalam proses pembelajaran matematika Kegiatan ini dapat dilihat sebagai proses siklik kumulatif dalam jangka panjang yang ditampilkan pada Gambar 1 berikut ini.

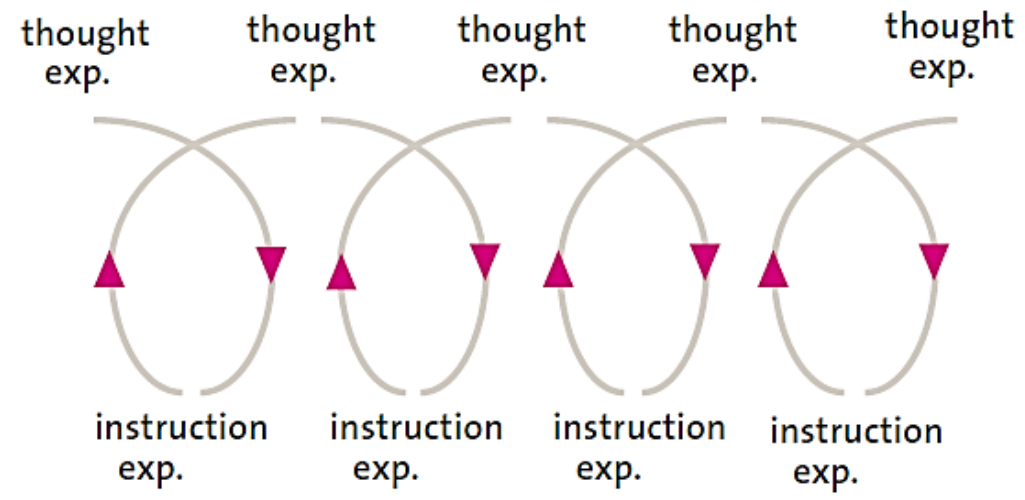

Gambar 1. Alur Penelitian Desain

(Plomp \& Nieveen, 2010)

Pada tahap persiapan (preparing for the experiment), terdapat beberapa studi literatur tentang topik yang akan digunakan untuk merancang HLT. Tahapan ini bertujuan untuk mengumpulkan semua data dan bahan yang dibutuhkan untuk mendesain HLT. Aktivitas selanjutnya adalah perancangan HLT. HLT yang dirancang ini bersifat dinamis sehingga dapat dilakukan revisi tergantung proses uji coba. Tahapan yang dilakukan dalam penelitian ini berupa kegiatan one to one yang merupakan tahapan percobaan pengajaran yang dicobakan ke beberapa subjek penelitian. Kegiatan one to one dilaksanakan pada hari Sabtu, tanggal 12 Desember 2020 di salah satu lembaga penyelenggara paket A tingkat 2 di Kota Bukittinggi.

Pada tahap one-to-one, rancangan HLT diuji coba pada tiga orang peserta didik Paket A Tingkat 2 yang terdiri atas peserta didik berkemampuan tinggi, sedang, dan rendah. Pada tahap ini penulis berperan sebagai peneliti untuk mengumpulkan data. Guru membantu dalam memilih peserta didik tersebut. Tahapan ini memiliki tujuan utama yaitu memberikan sumbangan pada pengembangan HLT dalam mendukung peserta didik untuk memahami materi. HLT berperan sebagai pedoman dalam menetapkan fokus analisis dalam penelitian. Hal-hal yang mempengaruhi dan mendukung keberhasilan proses belajar serta beberapa dugaan pembelajaran yang tidak direspon oleh peserta didik diproses dalam tahap analisis ini. Deskripsi yang dihasilkan digunakan dalam menarik kesimpulan serta menjawab pertanyaan penelitian. 


\section{Hasil dan Pembahasan}

\subsection{Hasil}

\section{Aktivitas 1: Membuat Pola}

\subsubsection{Siswa Berkemampuan Rendah}

Pada permasalahan pertama, peserta didik diminta untuk dapat merancang pola bilangan dengan media berupa batang korek api. Peserta didik diberikan kebebasan untuk menyusun pola bilangan dengan bentuk segitiga dan segiempat. Berikut ini dideskripsikan hasil kegiatan yang dilakukan peserta didik berkemampuan rendah. Berdasarkan Lembar Kerja Peserta Didik (LKPD) yang dikerjakan peserta didik, Peserta didik kurang dapat menjawab soal nomor 1 dengan tepat, membuat dua jenis pola namun hanya dapat menggambar pola sampai pola ketiga. Hal ini dilakukan peserta didik karena pada pertemuan sebelumnya sudah memencobakan pola ini dengan media manik-manik, namun peserta didik tidak mampu melanjutkan sampai pola yang diminta yaitu pola keenam, seperti terlihat pada gambar 2 berikut ini.

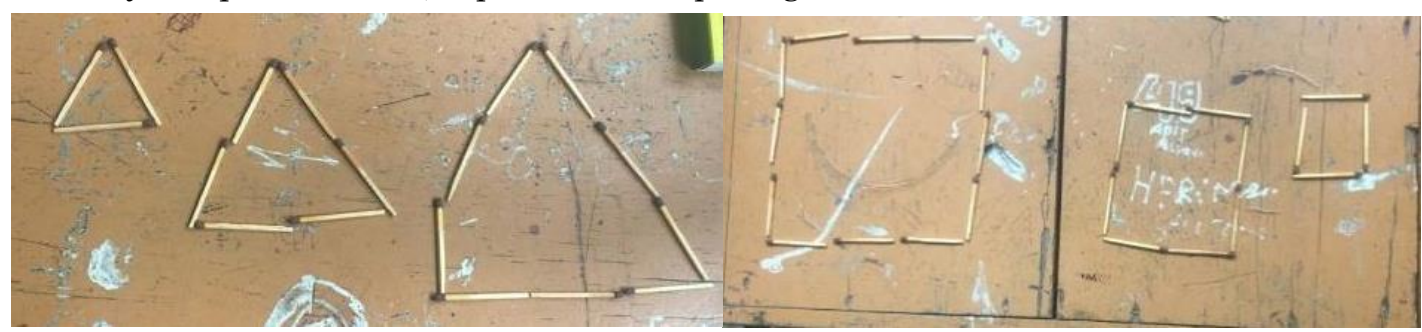

Gambar 2. Jawaban Peserta Didik Berkemampuan Rendah

\section{Wawancara:}

Pendidik : Ananda, mengapa membuat pola demikian?

Peserta didik : Karena minggu lalu bikin begini Bu dengan manik-manik.

Pendidik : Mengapa hanya 3 (tiga) pola yang Ananda buat?

Peserta didik : Saya ndak tau lanjutannya $\mathrm{Bu}$, saya binggung.

Pendidik : Coba Ananda perhatikan pola pertama sampai ke tiga yang Ananda susun, apa yang dapat ananda ambil perbedaannya?

Peserta didik : Ukuran dan jumlah batang korek apinya berbeda $\mathrm{Bu}$

Pendidik : Berapa perbedaannya?

Peserta didik : Masing-masing sisi bangun datarnya sepertinya ditambah satu lagi batang korek api untuk tiap urutan bangun yang dibentuk.

Pendidik : Kalau begitu bisa dilanjutkan pola keempat dan kelimanya?

Peserta didik : Bisa Bu

\subsubsection{Siswa Berkemampuan Sedang}

Berikut ini hasil analisis terhadap peserta didik berkemampuan sedang. Berdasarkan LKPD yang dikerjakan peserta didik, Peserta didik juga dapat menjawab soal nomor 1 dengan tepat, dengan membuat dua jenis pola namun hanya dapat menggambar pola sampai pola kelima. Peserta didik beralasan kertas untuk menempelkan pola yang dibuat tidak cukup untuk meneruskan pada pola berikutnya, seperti terlihat pada gambar 3 berikut ini. 


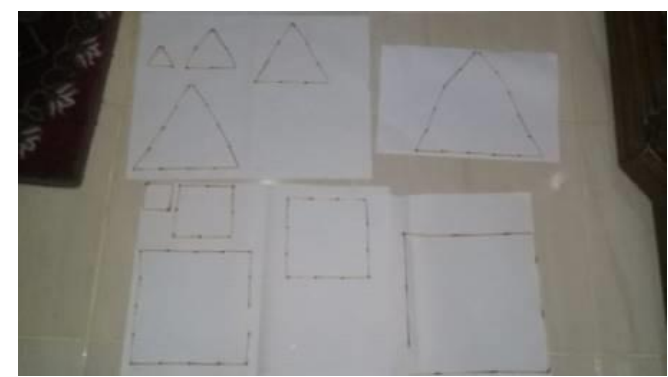

Gambar 3. Jawaban Peserta Didik Berkemampuan Sedang

\section{Wawancara:}

Pendidik : Ananda, mengapa membuat pola demikian?

Peserta didik : Karena ini yang saya bisa Bu

Pendidik : Mengapa hanya 5 pola yang ananda buat?

Peserta didik : Kertas saya ga cukup untuk menempel Bu, tapi saya mengerti.

Pendidik : Oke, kalau Ananda paham polanya, apa yang membedakan masing-masing pola yang ananda susun?

Peserta didik : Jumlahnya bu.

Pendidik : Ada apa dengan jumlahnya?

Peserta didik : Jumlah masing-masing korek api yang disusun berbentuk segiempat tambah lama semakin banyak.

\subsubsection{Siswa Berkemampuan Tinggi}

Hasil analisis terhadap LKPD yang dikerjakan peserta didik berkemampuan tinggi menunjukkan bahwa peserta didik dapat menjawab soal dengan tepat, meskipun tidak ada penjelasan pada jawaban. Peserta didik juga sudah dapat membuat pola berdasarkan soal yang diberikan meskipun hanya membuat satu jenis pola, seperti terlihat pada gambar 4 di bawah ini.

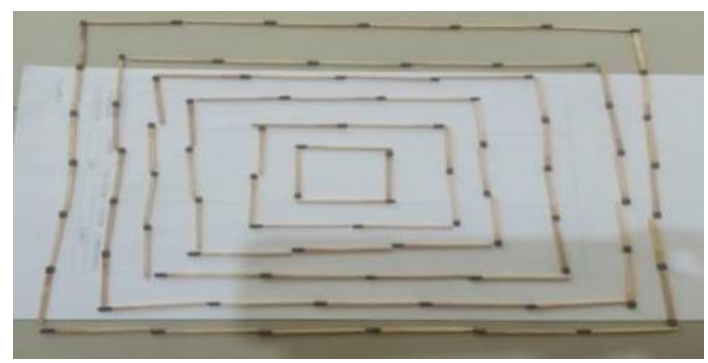

Gambar 4. Jawaban Peserta Didik Berkemampuan Tinggi

\section{Wawancara:}

Pendidik : Ananda, mengapa membuat pola demikian?

Peserta didik : Karena menurut saya tampilan seperti ini lebih menarik.

Pendidik : Apa yang membedakan tiap susunan pola tersebut?

Peserta didik : Jumlah tiap pola berbeda Bu, dengan penambahan 4 batang korek api di pola yang lebih besar.

\section{Aktivitas 2: Memprediksi dan Membuat Setiap Pola Bilangan yang Terbentuk Menggunakan Batang Korek Api}

Permasalahan kedua ditampilkan dalam pertanyaan 2 dan 3 dimana peserta didik diminta untuk dapat menghitung jumlah masing-masing pola yang disusun. Peserta didik menyusun pola tersebut dalam bentuk barisan bilangan. Peserta didik berkemampuan rendah mampu menjawab maksud pertanyaan yang diberikan tetapi hanya menuliskan jumlah korek yang 
digunakan dalam membuat pola tanpa memberi penjelasan. Pada tahapan ini, peserta didik diarahkan untuk menghitung pola yang ada sesuai urutan pola. Awalnya peserta didik menghitung secara keseluruhan batang korek api, kemudian dibimbing guru untuk menghitung satu persatu jumlah pola yang terbentuk. Pada kegiatan ini peserta didik ditanya kembali apa yang membedakan setiap pola dan peserta didik menjawab jumlah berbeda.

Peserta didik berkemampuan sedang mampu menjawab maksud pernyataan yang diberikan tetapi hanya menuliskan jumlah korek yang digunakan dalam membuat pola tanpa memberi penjelasan. Pada kegiatan ini peserta didik ditanya kembali apa yang membedakan setiap pola dan peserta didik menjawab jumlah berbeda. Pendidik juga menanyakan bagaimana menemukan pola-pola tersebut, peserta didik menyatakan menghitung jumlah korek api yang telah digunakan untuk setiap bangun datar yang terbentuk. Sedangkan peserta didik berkemampuan tinggi mampu menjawab maksud pertanyataan yang diberikan dengan memberi penjelasan jumlah korek tiap pola lalu menjumlahkannya. Pendidik memperkuat dengan pertanyaan lisan terkait penjelasan yang diberikan. Perhatikan gambar 5 di bawah ini.

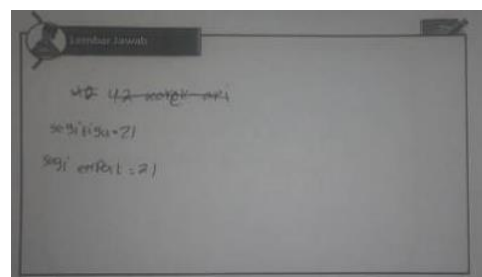

(a)

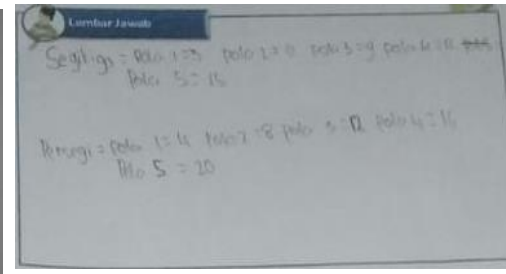

(b)

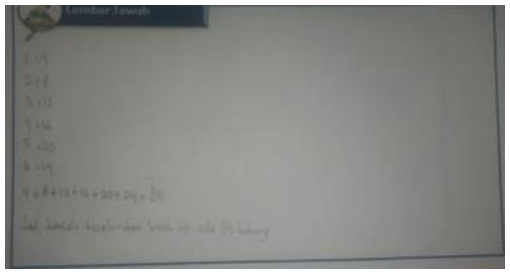

(c)

Gambar 5. Jawaban Peserta Didik Berkemampuan (a) Rendah, (b) Sedang, (c) Tinggi

Peserta didik berkemampuan rendah belum mampu menjawab maksud pertanyaan yang diberikan, siswa hanya menjawab berapa jumlah sisi bangun datar yang dia buat. Pendidik menanyakan mengapakah hal tersebut menjadi jawaban dan peserta didik menjawab bahwa dia memahami susunan pola yang dimaksud adalah bangun datarnya, bukan jumlah batang korek api yang digunakan untuk menyusun bangun datar. Sehingga, pendidik membimbing peserta didik agar mampu menentukan jumlah bilangan pada pola bangun datar secara tepat.

Peserta didik berkemampuan sedang sudah mampu menjawab maksud pertanyaan yang diberikan tetapi hanya menggambarkan pola tanpa memberikan penjelasan. Peserta didik memahami bahwa maksud dari menuliskan susunan pola bilangan dapat berupa gambar, hanya jumlah korek api yang digunakan saja yang ditandai dengan noktah. Pendidik menggali lagi pemahaman peserta didik ini dengan menanyakan apa yang membedakan pola yang terbentuk, dan peserta didik menjawab bahwa adanya perbedaan jumlah noktah yang mewakili jumlah batang korek api yang menyusun bangun datar. Dimana setiap pola yang terbentuk semakin lama semakin banyak dengan penambahan jumlah batang korek api yang digunakan. Ketika peserta didik diminta menentukan jumlah pola masing-masingnya, peserta didik menghitungnya satu persatu untuk tiap pola dan dapat menyebutkan dengan benar.

Peserta didik berkemampuan tinggi mampu menjawab maksud pertanyataan yang diberikan dengan memberi penjelasan jumlah korek tiap pola lalu menjumlahkannya. Peserta didik berkemampuan tinggi dapat menentukan dan menjelaskan dengan baik pola yang terbentuk dan menyebutkan adanya perbedaan yang ada dari setiap pola yang tersusun. 


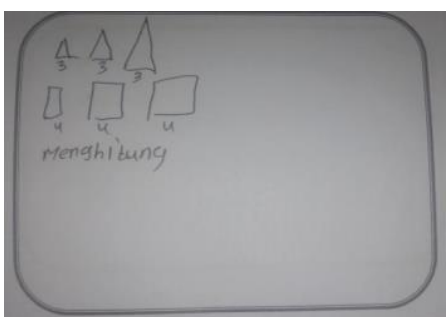

(a)

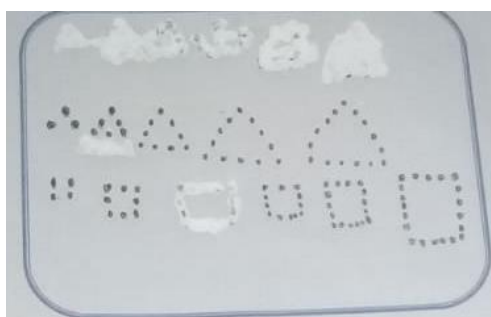

(b)

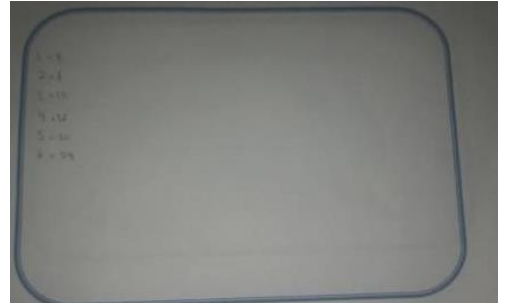

(c)

Gambar 6. Jawaban Peserta Didik Berkemampuan (a) Rendah, (b) Sedang, (c) Tinggi

\section{Aktivitas 3: Memformulasikan Pola Bilangan dengan Memperhatikan Beda Antara Po- la yang Terbentuk Guna Menyelesaikan Masalah}

Peserta didik berkemampuan rendah belum mampu menjawab maksud pertanyaan yang diberikan. Siswa memberi jawaban jumlah korek dalam mebuat pola ke enam dengan menghitung satu persatu korek yang dia gunakan. Pendidik menanyakan mengapakah jumlah yang diberikan adalah 21 , dan siswa menjawab dari hasil perhitungan yang dilakukan diperoleh hasil tersebut. Pendidik menanyakan apakah peserta didik yakin dengan jumlah hitungan tersebut dan meminta menghitung ulang. Peserta didik menghitung kembali dan ternyata ada hasil yang keliru sehingga perlu diperbaiki. Pendidik menanyakan kembali apa maksud satu persatu yang dituliskan dalam LKPD. Peserta didik menjawab bahwa cara yang dia lakukan secara cepat adalah dengan menghitung satu persatu. Pendidik mengarahkan peserta didik dengan meminta menentukan selisih antara pola tiap bilangan yang disusun. Peserta didik menentukan dengan mengurangkan pola yang besar dengan yang kecil dengan posisi berurutan. Hal tersebut dilakukan secara berulang dari pola satu sampai 6 sehingga ditemukan 5 selisih bilangan dari 6 pola yang terbentuk. Peserta didik menemukan adanya perbedaan yang sama. Sehingga guru mencontohkan untuk pola pertama dan kedua adanya pengalian antara urutan pola dengan selisih. Pada akhirnya untuk pola 3 sampai ke-6 peserta didik dapat menghitung dengan cepat dan mencocokan dengan jumlah batang korek api yang terpakai.

Peserta didik kemampuan sedang sudah mampu menjawab maksud pertanyaan yang diberikan, siswa memberi jawaban jumlah korek dalam membuat pola ke enam dengan memberikan cara cepat mencari jumlah korek untuk pola ke enam. Pendidik menanyakan mengapakah peserta didik menyatakan bahwa cara cepat yang dilakukan dapat dikali dengan 4 . Peserta didik menjawab bahwa dia menemukan adanya beda antara tiap pola yang terbentuk sebanyak 4 batang korek api. Setelah peserta didik mencobakan mengalikan urutan pola dan angka 4 ternyata hasil sama dengan jumlah batang korek api yang digunakan untuk menyusun pola tersebut.

Peserta didik berkemampuan tinggi mampu menjawab maksud pertanyataan yang diberikan dengan memberi penjelasan berupa cara cepat menghitung jumlah korek pada pola ke enam. Pendidik menanyakan mengapakah diperoleh cara cepat demikian, dan peserta didik menjawab bahwa adanya selisih tiap pola yang sesuai dengan hasil perkalian yang terbentuk dengan bilangan 4.

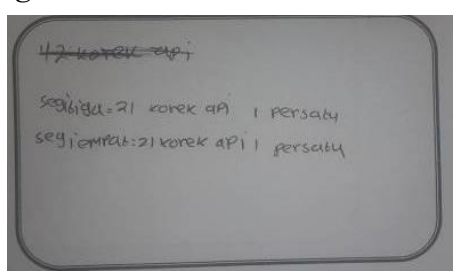

(a)

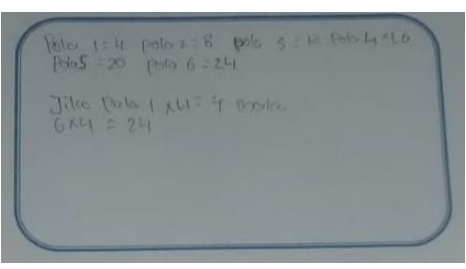

(b)

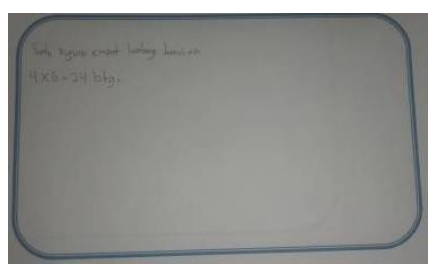

(c)

Gambar 7. Jawaban PD Kemampuan (a) Rendah, (b) Sedang, (c) Tinggi 


\section{Aktivitas 4: Memformulasikan Jumlah Pola Bilangan dengan Memperhatikan Beda An- tara Pola Yang Terbentuk}

Peserta didik berkemampuan rendah belum mampu menjawab maksud pertanyaan yang diberikan. Pada aktifitas ini belum dapat dicapai dengan baik. Peserta didik hanya mampu menjumlahkan tiap pola tanpa memperoleh hasil cara cepat yang dapat digunakan, meskipun telah diarahkan dengan menyusun bentuk tiap pola, peserta didik tetap belum mampu menentukan cara cepat.

\section{Wawancara:}

Pendidik : Ananda, apa maksudnya satu persatu?

Peserta didik : Dihitungnya Bu.

Pendidik : Apakah yang Ananda hitung?

Peserta didik : Batang korek api.

Pendidik : Bisakah Ananda praktikkan?

Peserta didik : Berhitung mulai dari angka 1 sampai 3 untuk pola pertama, dijumlahkan dengan 4-9 untuk pola kedua, danseterusnya sampai pola ke enam.

Pendidik : Kalau Ananda temukan jumlah semuanya seperti tadi untuk pola bentuk segitiga, mengapa jawabannya satu persatu?

Peserta didik : Karena ngitungnya satu-satu batang korek api, Bu.

Pendidik : Pendidik mengarahkan untuk menentukan jumlah keseluruhan pola dengan rumus cepat

Peserta didik berkemampuan sedang sudah mampu menjawab maksud pertanyaan yang diberikan, peserta didik memberi jawaban jumlah korek dalam mebuat pola keenam dengan menjumlahkan setiap pola korek yang dia gunakan. Namun peserta didik belum mampu memformulasikan rumus cepat dengan menggunakan pengetahuan sebelumnya tentang jumlah setiap pola pada aktivitas 3. Pada akhirnya juga pendidik mengarahkan untuk menentukan jumlah keseluruhan pola dengan rumus cepat.

Peserta didik berkemampuan tinggi mampu menjawab maksud pertanyataan yang diberikan dengan memberi penjelasan berupa cara cepat menghitung jumlah korek pada semua pola yang dia buat hanya saja dengan menambahkan keseluruhan pola bilangan yang terbentuk. Pendidik membantu mengarahkan untuk menentukan jumlah keseluruhan pola dengan rumus cepat dengan menjelaskan langsung.

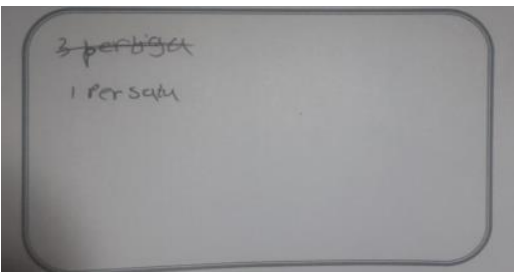

(a)

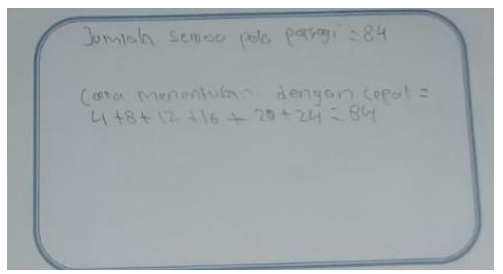

(b)

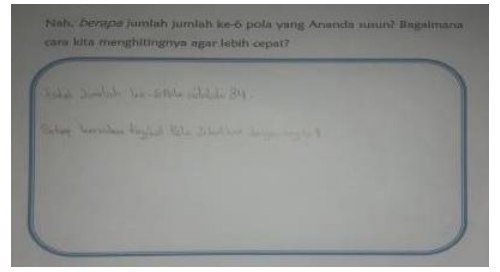

(c)

Gambar 8. Jawaban Peserta Didik Berkemampuan (a) Rendah, (b) Sedang, (c) Tinggi

\subsection{Pembahasan}

Penelitian pengembangan [2] yang dilakukan untuk melakukan pengembangan HLT. Berdasarkan rancangan awal HLT berisikan alur belajar dengan mempertimbangkan tingkat berpikir siswa (Yulia, 2018). Penelitian ini mengembangkan aktivitas berdasarkan prinsip RME. Rancangan aktivitas bertujuan meningkatkan komunikasi terhadap ide yang dimiliki. Pengimplementasian dibarengi dengan evaluasi formatif yang salah satunya adalah one to one (Tessmer, 2013 dalam Yulia, 2018). Tahapan uji one to one ini bertujuan untuk mengamati 
secara langsung jalannya HLT sehingga nantinya dari proses diketahui kemudahan dalam penggunaan serta dapat melakukan perbaikan sesuai kebutuhan pengguna (Yulia, 2018).

Pada kegiatan one to one dipilih tiga orang peserta didik dengan ketentuan yaitu masingmasing peserta didik yang dipilih adalah peserta didik yang memiliki kemampuan tinggi, peserta didik yang memiliki kemampuan sedang, dan peserta didik yang memiliki kemampuan rendah. Peserta didik berkemampuan rendah, berdasarkan pembahasan di atas, dari LKPD yang dikerjakan peserta didik, terlihat peserta didik belum mampu menemukan cara cepat menentukan pola bilangan untuk pola berikutnya. Peserta didik hanya langsung menghitung satu per satu korek api pada pola yang dibuat. Sehingga peserta didik dituntun dalam menemukan rumus cepat dan keberhasilan membangun pemikiran peserta didik secara mandiri hanya dapat terlaksana untuk menentukan jumlah tiap pola, tidak untuk jumlah keseluruhan.

Peserta didik berkemampuan sedang. berdasarkan pembahasan di atas, dari LKPD yang dikerjakan peserta didik, terlihat peserta didik sudah mampu menemukan cara cepat menentukan pola bilangan untuk pola berikutnya. Tetapi pada aktivitas berikutnya peserta didik belum mampu menentukan cara cepat menghitung jumlah seluruh pola. Peserta didik hanya langsung menghitung satu persatu korek api pada pola yang dibuat.

Peserta didik berkemampuan tinggi, berdasarkan pembahasan di atas, dari LKPD yang dikerjakan peserta didik, terlihat peserta didik sudah mampu menemukan cara cepat menentukan pola bilangan untuk pola berikutnya. Pada aktivitas berikutnya peserta didik mampu menentukan cara menghitung jumlah seluruh pola, hanya saja dengan menambahkan pola bilangan yang terbentuk. Sehingga pendidik menjelaskan cara cepat dalam menghitung keseluruhan pola yang sudah disusun.

Berdasarkan aktivitas yang telah dilakukan untuk tiga kemampuan di atas dapat disimpulkan bahwa kemampuan peserta didik yang rendah memang mengalami kesulitan dalam menemukan cara cepat menetukan pola berikutnya dan cara cepat menghitung keseluruhan jumlah pola dengan adanya antisipasi pendidik serta bimbingan pada aktivitas berikutnya peserta didik bisa melanjutkan pola berikutnya walau masih keliru, namun tidak mampu juga membangun cara menghitung cepat keseluruhan pola. Peserta didik dengan kemampuan sedang dapat memahami masalah konteks dengan mencari berbagai kemungkinan, dan mengaitkan angka yang ada pada konteks untuk mencoba dugaan dalam menentukan pola. Sedangkan peserta didik dengan kemampuan tinggi, dapat memahami permasalahan kontekstual dengan membuat pola bahkan dapat menyelesaikan pola tersebut karena sudah punya konsep yang kuat dengan belajar tambahan. Peserta didik kemampuan sedang dan tinggi sudah sampai pada tahap formal untuk menentukan pola bilangan untuk urutan berikutnya secara cepat dengan formulasi yang mereka temukan. Namun belum mampu memformulasikan jumlah pola secara keseluruhan.

Pelaksanaan pembelajaran cenderung lama, karena peserta didik yang masih banyak memilih diam ketika diberi pertanyaan mengenai masalah yang dipelajari tersebut. Sehingga guru memerlukan usaha yang ekstra agar peserta didik dapat menemukan cara untuk menyelesaikan permasalahan yang diberikan. Konsentrasi peserta didik juga berkurang, sehinga kesulitan dalam mengkondisikan pembelajaran yang baik. Hal ini juga mengakibatkan pembelajaran yang dilaksanakan terkesan kurang efektif.

Berdasarkan aktivitas yang dilaksanakan peserta didik, dan dengan menggunakan HLT ini peserta didik dapat dengan sendiri menemukan model matematika dari pola bilangan. Pada akhir pembelajaran ditekankan kembali bagaimana menentukan pola ke-n dan jumlah pola ke-n. Apa yang diprediksi dan antipasi yang dibuat pada desain HLT terlaksana dengan tepat, walaupun di bawah bimbingan guru dan didukung dengan wawancara pada peserta didik. 
Menurut Bakker bahwa HLT merupakan hubungan antara suatu teori pembelajaran (instructional theory) dan uji coba pengajaran yang sebenarnya, yang dilaksanakan untuk topik pola bilangan pada peserta paket A tingkat dasar. Menurut Fauzan dalam Yulia (2018) proses matematisasi horizontal dan vertikal berdasarkan permasalahan kontekstual pada pertanyaan 1 yang diberikan pada LKPD dapat disimpulkan bahwa penggunaan konteks guru akan membuat figura dengan hiasan tepi batang korek api digunakan sebagai titik awal pembelajaran matematika terjadi aktivitas eksplorasi, peserta didik telah mampu membuat model matematika sesuai dengan masalah kontekstual yang diberikan. Untuk melakukan matematisasi secara progresif disajikan pertanyaan 2 yang memperlihatkan aktifitas membuat model matematika dengan menentukan jumlah tiap pola yang ada pada masalah kontekstual, dalam hal ini peserta didik telah mampu membuat model matematika dalam bentuk pola bilangan. Untuk matematisasi horizontal, peserta didik menyelesaikan soal-soal yang ada pada pertanyaan berikutnya (3 dan 4) dengan cara mereka sendiri, dengan menggunakan bahasa yang mereka pahami. Dalam matematisasi vertikal, peserta didik menyelesaikan pertanyaan 5 secara langsung media dan tanpa gambar. Peserta didik membuat pola dengan mengalikan dengan bilangan tertentu agar perhitungan lebih mudah dan cepat.

Pelaksanaan pembelajaran cenderung lama, karena peserta didik yang masih banyak memilih diam ketika diberi pertanyaan mengenai masalah yang dipelajari tersebut. Sehingga guru memerlukan usaha yang ekstra agar peserta didik dapat menemukan cara untuk menyelesaikan permasalahan yang diberikan. Uji coba one to one diadakan pada jam terakhir sebelum pulang sekolah. Konsentrasi peserta didik juga berkurang, sehinga kesulitan dalam mengkondisiskan pembelajaran yang baik Hal ini juga mengakibatkan pembelajaran yang dilaksanakan terkesan kurang efektif.

\section{Kesimpulan}

Berdasarkan hasil ujicoba dapat disimpulkan bahwa hypothetical learning trajectory dapat diterapkan pada topik pola bilangan di salah satu penyelenggara Paket A tingkat 2 di Kota Bukittinggi. Pada penerapan one to one, peserta didik berkemampuan sedang dan tinggi dapat membuat jawaban sesuai apa yang diprediksi pada HLT, namun untuk peserta didik berkemampuan rendah, guru memberikan antisipasi-antisipasi sehingga peserta didik dapat menyelesaikannya.

\section{Daftar Pustaka}

[1] Akker, J. van den, Bannan, B., Kelly, A. E., Nieveen, N., \& Plomp, T. (2018). Educational Education and development. Netherlands Institute for Curriculum Development (SLO), 5. Bakker, Utrecht . 2004. Design research in statistics education: On symbolizing and computer tools / A.CD-B Press, Center for Science and Mathematics Education - (CD-B wetenschappelijke bibliotheek; nr. 50; 2004). Dissertation Utrecht University. - With references. - With a summary. - Met een samenvatting in het Nederlands.

[2] Gravemeijer, Koeno and Cobb, Paul. (2013). Design research from the Learning Design Perspective. Dalam Jan Ven Den Akker, et. al. Educational Design Research. London: Routledge.

[3] Graveimejer K, J Bowers, M. Stephen, Chapter 4. Hypotethical Learning Trajectory on Measurement and Flexible Aritmetic . p. 52-66 (2014).

[4] Mohammad Tohir. (2019). Hasil PISA Indonesia Tahun 2018 Turun Dibanding Tahun 2015. https://matematohir.wordpress.com/

[5] Nukuhaly, N. A., Assagaf, G., \& Muhamad, J. (2018). Analisis Kesalahan Dalam Menyelesaikan Soal- Soal Pola Bilangan Pada Siswa Kelas VIII, 103-111. 
[6] Rangkuti, Ahmad Nizar. (2015). Pengembangan Alur Pembelajaran Topik Pecahan di Sekolah Dasar dengan Pendekatan Pendidikan Matematika Realistik. Padang: Program Pascasarjana UNP.

[7] Yulia, A. Fauzan, N. Gistituati, and Yerizon, "Intructional Design or Teaching Sets Using RME Approach at Junior High School," International Conference on Science and Technology 2018, Applied Science and Technology, (2018) p. 261-267

[8] Yusri, Y., \& Arifin, S. (2018). Desain Pembelajaran Kooperatif Berbasis Teori Bruner Untuk Meningkatkan Kualitas Pembelajaran Matematika. HISTOGRAM: Jurnal Pendidikan Matematika, 2(2), 147. https://doi.org/10.31100/histogram.v2i2.233

[9] Wijaya, Ariyadi. 2012. Pendidikan Matematika Realistik, Suatu Alternatif Pendekatan Pembelajaran Matematika . Yogyakarta: Graha Ilmu. 